\title{
Role of Fishery and Forest Resources in Local Economic Performance: Evidence from the Lake Zone of Tanzania
}

\author{
Isege Z. Mihayo ${ }^{1,2}$ \& Daiyan Peng ${ }^{1}$ \\ ${ }^{1}$ School of Economics, Huazhong University of Science and Technology, Wuhan, China \\ ${ }^{2}$ School of Environmental Sciences and Technology, Univeristy of Dodoma, Dodoma, Tanzania \\ Correspondence: Isege Z. Mihayo, School of Economics, Huanzhong Univesity of Science and Technology, 1037 \\ Luoyu Road, Wuhan, 430074, P.R. China. Tel: 86-130-0710-6453; 255-752-447-886. E-mail: \\ isegemihayo@yahoo.com
}

Received: November 28, 2019

Accepted: January 10, 2020

Online Published: January 15, 2020

doi:10.5539/ijef.v12n2p22

URL: https://doi.org/10.5539/ijef.v12n2p22

\begin{abstract}
The country's economic development usually occurs at a local level where interactions between economic elements are highly dense. Even though economic development processes are highly localized; economic growth in the country is due to concentration in growth in a limited number of locations with unique comparative advantages. Lake zone of Tanzania is one of the potential economic areas in the country with unique natural resources (fisheries and forests) features. This study uses cross-sectional data in the lake zone of Tanzania to determine the impact of the fishery resources (which are highly abundant) and forest resources (which are least abundant) on the local councils' economic performance, admitting other control variables. Multiple linear Regression analysis results indicate that fishery resources negatively affect the councils' economic performance, with insignificant economic value. Forest resources in the area have a significant positive impact on the economic performance. This paper concludes that despite the abundant fishery resources in the area, they have an insignificant contribution to the local councils' economic performance. Moreover, the least forest resources have a very low economic impact on local economic performance. Which therefore indicate the needy of reforming available strategies, policies and legal framework accordingly.
\end{abstract}

Keywords: economic performance, fishery, forest, resources

\section{Introduction}

Local economic performance is significant for the economic development of a country as a whole. The country's economic development occurs at a local level where interactions between economic agents are particularly dense (Manso, De Matos, \& Carvalho, 2015). Combination and integrations of related elements at the local levels in specific ways, formulate the processes of new knowledge generation, innovation, collective learning and, eventually, economic performance based on the unique local features (Amin \& Thirf, 1993; Ascani, Crescenzi, \& Iammarino, 2012; Cooke, Uranga, \& Etxebarria, 1998). Several interactions between relevant local elements are highly supported by an institutional framework that shapes the innovative capacity of specific local contexts and allows the absorption and employment of exogenously produced knowledge and capacity in an economically productive way (Iammarino, 2005). In addition to that, Local economic developments are highly supported by the understanding and applications of competitive advantages based on locations functional capabilities and competencies nurtured by socio-institutional and social structures (Ascani et al., 2012; Goletsis \& Chletsos, 2011; Pike, Rodríguez-Pose, \& Tomaney, 2010). All these facts encourage and facilitate knowledge transmission and exploitation at a regional basis.

Even though economic development processes are highly localized, not all local places are equally able to prosper in the country and global competitive environment. Some studies suggest that national growth is often led by only a few fast-growing and innovative areas within a country (Ascani et al., 2012; Manso et al., 2015). Knowledge and development activities require a favorable atmosphere to make positive feedback to the applied interactions possible. Therefore, differences in local political, social, and institutional features determine different interactions between local economic agents, knowledge and innovation activities, and hence their economic outputs. All these confirm the point that the level of economic growth in the country is due to concentration in growth in a limited number of locations as some studies indicate (Carlino, Chatterjee, \& Hunt, 


\section{1; Crescenzi \& Rodríguez-Pose, 2011).}

In developing countries, the localized nature of economic development and the importance of socio-institutional factors appear even more crucial, since desirable locations and contexts become less likely (Ascani et al., 2012; Milanovic, 2005; Zhang \& Zhang, 2003). This is because of the stable patterns of spatial inequalities experienced by most developing countries in the past few years, witnessed by the great economic developments in few locations, as compared to the remaining areas within the same country. All these indicate that economic development processes in developing countries are solidly fixed in particular densely developed areas, which drive national growth by competing in international mark whereas the rest declines with limited benefits from globalization and integration processes. This pattern eventually produces uneven economic development in the countries.

Tanzania, as a developing country, has its economic development and performance fixed in some areas. Lake zone of Tanzania represents one of the economy active areas in the country. The area has a high population growth (United Republic of Tanzania [URT], 2018b) surrounded by all the East African countries that mark it as an economical gate into and from the countries (Odongkara, Abila, \& Onyango, 2005). Additionally, one of the main factors that boost the economy of the area is the availability of natural resources. Lake zone of Tanzania has the highest fishing activities in the country with more than $70 \%$ of all the fishing activities (Luomba \& Onyango, 2012). Apart from fishery, Lake Zone also has forest resources. However, on the contrary, forests are in the least state (National Forestry Resources Monitoring and Assessment [NAFORMA], 2015). Availability of sustainable natural resources could be a deciding factor for economic developments, especially in terms of productivity and sustainability, as fishery resources in the lake zone have mentioned to significantly contribute to the Gross Domestic Product (GDP), Exports, formal and informal employment in the country (Mgale \& Nikusekela, 2017; URT, 2018a). Forest resources also have a significant contribution to the country economic output as a whole (Kideghesho, 2015; Mgaya, 2016). Given the status of the resources (fishery-high abundant, forest-least abundant), it was of interest to compare their contribution in local economic performance. As most of the studies in the country and related countries are from cross-country and macroeconomic analyses. Thus, this study aims to identify the impact of fishery and forest resources in the local economic performance of the lake zone of Tanzania. In line with these, based on the reviewed literature, other determinants of the local economic performance are also considered.

\section{Theoretical Approach}

Local (regional) development in a country is a subject of global and local contexts (Kuznets \& Murphy, 1966; Manso et al., 2015; Peters, Simsek, \& Acemoglu, 2009). Generally, the main factors that determine local economic performance are classified as economic, human (health, education, and skills), social, cultural, and natural resources (Bronzini \& Piselli, 2009; Courtney \& Moseley, 2008; Jackson \& Murphy, 2006; Manso et al., 2015; Rutten \& Boekema, 2007). All these factors have their link with the local economic growth and performance, which captures the multi-faceted nature of human development and enables comparison across different factors. The policy framework of the country and institutional setting induce economic growth, performance, and development of regions and forces inevitably the development scenarios of the regions in countries.

The impact of natural capital and economic performances have been discussed in different perspectives. Some studies have identified a negative impact of natural resource abundance on economic growth and performance (Philippot, 2010); most of these studies are of the country level. The regional related studies are explained by highlighting the importance of local institutions. Two sets of institutions that might be relevant at the local level are political institutions and fiscal decentralization arrangements (Aragón, Chuhan-Pole, \& Land, 2015; Jin, Qian, \& Weingast, 2005; Kmezić \& Đulić, 2018). All these include the rules to select reputable politicians, re-elect incumbents, and restrict an incumbent's power, rules that define how fiscal revenue will be collected, distributed and used at the subnational level (Aragón et al., 2015). The practical implementation of national and local policies, together with a high degree of cooperation between the public, private and voluntary sectors play an essential role, in influencing the economic outputs from the factors of production in a local area.

Regional growth studies have also been incorporated with innovation, competitiveness, technology (Ascani et al., 2012; Bronzini \& Piselli, 2009; Jackson \& Murphy, 2006; Rodríguez-Pose \& Crescenzi, 2008). Technology, by itself, is an essential factor, but not sufficient condition to take a local area to the next level of economic performance (Manso et al., 2015; Rutten \& Boekema, 2007). Some authors argued that even though technology and knowledge have increased well in terms of availability and accessibility, with a high level of production (Ascani et al., 2012; Gibbons, 1994; Manso et al., 2015), but they have not analyzed the regional system 
thoroughly with its requirements and the influencing factors. These factors are indeed essential for understanding the territorial differences in terms of development. Innovations make customers surrounded by them more interested in products and services, which make their lives more convenient and are attached to the values. Though it can be argued that development in technology is just one of the combinations of different types of knowledge that innovation requires (Batenburg \& Rutten, 2003; Rutten \& Boekema, 2007), the increasing availability and integration of knowledge and technology into production and the capital gains that arise to society from it are not territorially homogeneous.

Various works of literature have incorporated local economic growth and performance with the neo-classical models of economic development, whereby the output is a function of labor and capital (Courtney \& Moseley, 2008; Terluin, 2003). The drivers of local economic development and performance fall across a continuation of exogenous models, driven by external resources, to endogenous factors (economic and non-economic), where local capabilities and resources enable the development. The theory of regional development is another theoretical support of the matter in terms of new economic geography (Manso et al., 2015), whereby, geographic concentrations are explained by transaction costs, efficiency, and commercial and economical specializations (Scott \& Storper, 2003). Regional network theories describe regional development as the result of the interaction of agents within and between networks (Rutten \& Boekema, 2007). The interaction within and between them, lead each region to specialize and to have a particular economic and social structure. Regional economic growth thus results from the interactions between and within innovation, social networks, and the tangible and intangible assets, that includes knowledge and technology (Carney, 2002; Cooke, 2002).

The spatial equilibrium model, initially developed by urban economists, can also explain the study. The most widely used model is the Rosen-Roback framework (Glaeser \& Gyourko, 2006). The model explains that a country is composed of several local economies like cities and municipalities. Every local area produces a single internationally traded using labor, land, and a local amenity. Workers utility depends on nominal wages, cost of housing, and local amenities. Labor is homogeneous and entirely mobile. The land is the only immobile factor, and its supply is fixed. The critical insight of this model is that, due to perfect mobility, the utility of workers in every city should be the same (Glaeser, 2007). Thus, any local shock to the demand for labor is adequately capitalized into land prices. In equilibrium, shocks to the local economy (such as a resource boom) benefit mostly the owners of immobile factors, such as landowners (Hsieh \& Moretti, 2019). Therefore, in this case, the real national wage may increase with no difference in real wage between locations. This extreme result, however, is explained by the assumption that the elasticity of housing supply is limited while local labor supply is infinitely elastic (Albouy \& Stuart, 2014).

\section{Methodology}

Economic development in a country or a local area is usually conceptualized as an increase in average income per capita. Many related studies strive to identify the main economic factors influencing it (Aragón et al., 2015; Solarin, Al-Mulali, Musah, \& Ozturk, 2017; Van der Ploeg \& Poelhekke, 2009; Wu, Li, \& Li, 2018). Therefore, this study uses income per capita of 30 different administrative councils found in five regions of Lake Zone of Tanzania as an indicator of economic performance. In the quantification of the resources, fishery and forest Resources have been measured using different relating elements. Fishery resources were measured using the abundances of fishes corrected in the local councils. The forest resources have been measured using the total forested area in the councils.

Districts in Tanzania differ considerably in natural resource endowments, population, human capital, poverty incidence, and urbanization rates. All these have made the districts to be classified into local government authorities (councils) based on the level of development. The country has mainly four councils, which are three urban councils (city, municipal, and town) and rural council (Zhihong, Abdulrahman, \& Xiaoying, 2014). Therefore, the type of council is also included as a determinant of the area economic performance.

Education is highly associated with the innovative capacity; that in turn drew attention to the role of the level of education in labor force, human capital, which according to economic literature is the basis of production (Madrian, 2014; Mankiw, 2014). Areas with higher educational attainment are associated with a higher rate of economic growth since the members of the community are expected to be well experienced with innovative ideas to boost up the economy (Manso et al., 2015). As this study used the lower level of administrative authorities (councils), and with the lower number of higher education institutions in the country, a number of educational colleges and higher education institutions as a combination are included in the study.

Health related-factors are also included as determinants. There is a link between economic performance and different health-related factors, and this includes the number of doctors and related professionals (Manso et al., 
2015), number of hospitals and health centres. Many related studies reveal a strong positive correlation between health and economic growth. Presence of a high number of doctors and other health professionals, a good number of hospitals and health centers influence good human indicators such as life expectancy at birth, maternity mortality rate, infant mortality rate that in turns offers ability and capability to boost the economic growth (Bloom, Canning, \& Sevilla, 2004).

\subsection{Multiple Linear Regression Analysis (MLRA)}

Multiple linear regression analysis (MLRA) is among the most widely used statistical techniques to understand the relationship between several independent variables and a dependent variable, (Abdipour, Younessi-Hmazekhanlu, \& Ramazani, 2019; Lee, Lee, \& Hwang, 2019). The general expression for standard MLRA is given by:

$$
Y=\beta_{0}+\beta_{1} X_{1}+\ldots \ldots . . \beta_{n} X_{n}+\varepsilon
$$

Where $\mathrm{Y}$ is the dependent variable, $\mathrm{x}$ and $\mathrm{n}$ are independent variables, $\beta$ are the coefficients, and $\varepsilon$ is the random error.

Therefore based on the backdrop, this study uses multiple linear regression analysis to determine the local economic impact of availability of fishery resources and forest resources using STATA statistical software package. Additionally, number of doctors, hospitals and health centres, number of colleges and higher education institutions, level of councils development, and population density also used. Data are cross-sectional obtained from Tanzania national bureau of statistics, Ministry of regional administration and local government, ministry of natural resources and tourism, Tanzania fishery Research Institute (TAFIRI)-Mwanza centre, and respective local councils in the lake zone.

Following the research and theoretical basis of this study, the form of the model is specified as:

$$
\text { Inccap }=f\left(\text { Nat }_{i}, E d u_{i}, \text { doct }_{i} \text {, health }{ }_{i}, k_{i}\right) v_{i}
$$

Where, inccap is income per capita, Edu represent the number of colleges and higher learning institutions, Nat is the level of natural resources and for this case is forests and fisheries, doct is the number medical doctors per 10000 inhabitants, health is the number of hospitals and health centres. $\mathrm{K}$ is a vector of other explanatory variables that can cause variations in income per capita as population density, level of development, institutional quality, trade, presence of cultural, museums and tourism attractions, etc. $v$ is the unestimated error term. The subscript i represents a given council.

Thus, the exploited structural model of the MLRA is:

Where:

$$
\text { Inccap }_{i}=\beta_{0}+\beta_{1} \text { For }_{i}+\beta_{2} \text { Fis }_{i}+\beta_{3} E d u_{i}+\beta_{4} d c_{i}+\beta_{5} H_{i}+\beta_{6} \text { pop }_{i}+\beta_{7} \operatorname{dev}_{i}+\varepsilon
$$

- inccapp is the income per capita in the council.

- For is the total forested land in council i measured by ha.

- Fis is the fish species abundance in the council i, measured in metric tons.

- Edu in the total number of colleges and higher learning institutions in council i.

- dc in the total number of medical doctors per 10000 inhabitants in i council.

- $\mathrm{H}$ is the number of hospitals and health centres in $\mathrm{i}$ council.

- $\quad$ pop is the population density in i council measured by a number of inhabitants in $\mathrm{km}^{2}$.

- dev is the level of council development. $\beta$ represent respective coefficient,

- and $\varepsilon$ is the error term.

\subsection{Model Performance Evaluation Criteria}

The capability of regression models to determine the economic performance in the area was tested by the Doornik-Hansen test for multivariate normality to check if the variable are normal distributed. Also graph was also drawn to identify the linear relationship between the dependent variable and independent variables, and the relationship between the independent variables.

\section{Results}

Before the preliminary tests, it is required that a description of the data, which is needed to know the average rate of the data including the variation of the variables around their averages as well as to know the descriptions, distribution pattern of the investigated variables (Table 1). 
Table 1. Variables used and hypothesis for describing the local economic performance

\begin{tabular}{|c|c|c|c|c|c|}
\hline Independent variable & Description and measuring type & mean & $S D$ & Variable type & Expected sign \\
\hline Forests & Total forested land in the council measured by hectares & 12785.7 & 9356.1 & continuous & + \\
\hline Fishery & Fish abundances in metric tons & 10939.06 & 9877.25 & continuous & + \\
\hline Education & Number of colleges and higher learning institutions & 2.6 & 1.8 & continuous & + \\
\hline Doctors & Number of medical doctors per 10000 inhabitants & 6.7 & 4.5 & continuous & + \\
\hline Health & Number of hospital and health centres & 36.2 & 13.3 & continuous & + \\
\hline Population & Population density in number of habitant in $\mathrm{Km}^{2}$ & 1450.5 & 8181.4 & continuous & + \\
\hline \multirow[t]{5}{*}{ Development } & Level of council development & & & Categorical & \\
\hline & City & .03 & .2 & & + \\
\hline & Municipal & .1 & .3 & & \pm \\
\hline & Town & .2 & .4 & & \pm \\
\hline & District & .7 & .5 & & \pm \\
\hline
\end{tabular}

\subsection{Preliminary Analyses}

Doornik-Hansen test for multivariate normality shows data are normally distributed at chi2 of 192.442 and a 0.01 level of significance. A correlation matrix results that was also done to determine perfect dependence among the independent variables are showing that level of development is highly correlated with education and the number of doctors at a 0.05 level of significance. Also, population density has a higher correlation with fishery, forest, and health facilities at 0.05 level of significance (Table 2). All these indicate a sign of multicollinearity, and this was confirmed by the after regression variation inflation factor (VIF) test whose values were higher than 10. Based on that, population density and level of development were removed from the regressors.

Table 2. Correlation matrix

\begin{tabular}{|c|c|c|c|c|c|c|c|c|}
\hline Variables & Inco. & Population & Fishery & Forest & Health & Dev. & doctors & education \\
\hline Income per capita. & 1 & & & & & & & \\
\hline Population & -0.0581 & 1 & & & & & & \\
\hline Fishery & -0.2210 & $0.3891^{*}$ & 1 & & & & & \\
\hline Forest & 0.0830 & $0.4916^{*}$ & $0.3847 *$ & 1 & & & & \\
\hline Health & 0.0547 & $0.6689^{*}$ & 0.1603 & 0.0554 & 1 & & & \\
\hline Development & $-0.6751 *$ & 0.1793 & 0.0947 & 0.2234 & 0.0047 & 1 & & \\
\hline Doctors & $0.7209^{*}$ & $0.7510^{*}$ & -0.0807 & -0.1141 & $0.4613^{*}$ & $-0.6873^{*}$ & 1 & \\
\hline Education & $0.5082 *$ & 0.2723 & 0.0332 & -0.0937 & $0.4012^{*}$ & $-0.5944 *$ & 0.1322 & 1 \\
\hline
\end{tabular}

$* \mathrm{P}<0.05$.

Results from the linear relationship matrix graph of dependent variable and the remained independent variables indicate that there is no perfect relationship between independent variables, which prove no muliticolinerality. In addition, the results indicate linear relationship between dependent variable and the independent variable as indicated in the figure 1.

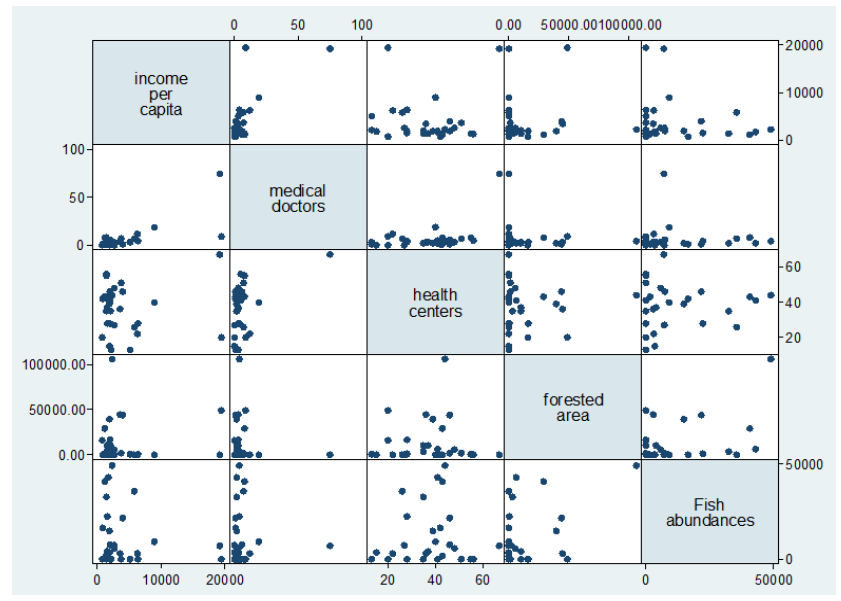

Figure 1. Graphic presentation that indicate linear relationship between variables 


\subsection{Factor Affecting Local Councils' Economic Performance}

The multiple regression analysis was used to determine the impact of forest and fishery resources, number of hospitals and health centres, number of doctors, and number of educational institutions on the local councils' income per capita as a measure of economic performance.

Results are showing that the number of colleges and higher learning institutions has an insignificant impact on the council's economy. Regardless of this, some related studies have found a significant impact. That includes Soukiazis and Antunes (2011) Bucci and Segre (2011) and Manso et al. (2015). Fishery resources were found to have a negative significant impact on the council's economy, with insignificant economic value (less than $0.1 \%$ ). Despite lake zone having the highest fishery resources (Luomba \& Onyango, 2012), more than 70\% of fishing activities in the area are illegal (URT, 2018a), that make difficult for the responsible authorities to track fishery resources, related products, and the revenues. In addition to that, there is a high number of foreign fishers who come to fish in the area, and their fishing is not of the country's benefit.

Forest resources in the area have a significant positive impact on the income per capita at 0.05 level of significance. However, the impact is not of economic value since it is less than $0.01 \%$ as table 3 show. Other related studies have also indicated a positive relationship between forest resources and economic growth (Agrawal et al., 2013). Cuaresma et al. (2017) found that there is a negative relationship between forest cover and per capita income growth, and the relationship is very active in the early stages of development.

A number of hospitals and health centres have a negative significant impact on the income per capita in the area at 0.05 level of significance. From the respective coefficient, results indicate that the presence of hospitals and health centres in the area decrease the income per capita by $2 \%$. The number of medical doctors has a significant positive impact on the income per capita in the area at $0.01 \%$ level of significance, indicating that the presence of medical doctors increases income per capita by 3\%. This is obvious because the presence of enough health professionals in the area is among the essential constituents of human capital (Sharma, 2018). Human capital is an essential factor of production (Mankiw, 2014) and therefore increase the economic outputs. These results are in contrary to those presented by Manso et al. (2015), who found that medical doctors have a negative impact on the regional growth in Portugal.

Diagnostics tests test for heteroscedasticity was conducted after fitting the regression analysis to test the adequacy of the fitted model. Results are found to be not significant ( $\mathrm{x} 2=1.11$, $\mathrm{p}$-value $=0.2928)$, that largely support the stability of the coefficients of regression equations.

Table 3. Regression analysis of the factor affecting local economy performance

\begin{tabular}{lllll}
\hline Independent variables & coefficient & Standard errors & P value & VIF \\
\hline constant & 8.35 & .323 & 0.000 & \\
Fishery & -.00003 & .000020 & 0.063 & 1.25 \\
Forest & .000010 & 0.0004 & 0.054 & 1.19 \\
Doctors & .035 & .0126 & 0.009 & 2.58 \\
Health & -.022 & .009 & 0.024 & 1.35 \\
Education & .046 & .0428 & 0.285 & 2.36 \\
Number of observation 30 & & & & \\
R-squared =0.5781 & & & & \\
F value $=6.58$ & & & & \\
$\mathrm{P}=0.0006 \quad$ & & & \\
\hline
\end{tabular}

\section{Discussion}

The abundant resources in the area have to benefit the surrounding community economically, socially, while maintaining its nature. The lake zone of Tanzania has the most abundant fishery resources in the country, but the resources seem to be unsustainably utilized, that led to an insignificant impact on the local economy. The government of Tanzania has mentioned that implementation of natural resources policies as one of the ways to improve the economic outputs and households' livelihood. However, currently, data from Lake Zone does not prove the case. There is a high number of illegal related activities (URT, 2018a) that confirm weak enforcement of the laws and policies, which in turns makes it difficult for the responsible authorities to track fishery resources and the revenues. As it has been further indicated by the URT (2018a), Tanzania Revenue Authority (TRA), and other local authorities collect only less than $25 \%$ of all the revenues and incomes, which is supposed to be collected from fishes and fishery product in the lake zone.

Some studies concluded that there is an association between forest resources and income, some indicating 
economic activities and output affecting the forest cover (area) and the other forest cover causing increase the economic outputs (Agrawal et al., 2013; Ewers, 2006). Mostly the change transitions in forest cover (afforestation) is a result of government intervention from the policies implications. Tanzania's government once mentioned that most of the natural resource policies have sustainable economic development elements (Kabubu, 2012; URT, 2012). However, results are in contrary to that, implying that either the policies are not well implemented as long as of raising economic outputs is concerned or does not have economic elements.

This study also supports the evidence obtained in the literature that established policies need reforms to meet the current economic needs (Sharma, 2009). Formation and implementation of natural resources related policies can be the easiest pathway to a sustainable economy in a local area. However, the fact is that, efforts have to go further, and other strategies and measures cannot be ignored.

This paper has explored an important area urgently relevant for responsible authorities to address to attain sustainable economic growth in a local area with unique features that may lead to the economic development of a country as a whole. Sustainable utilization of natural resources can indeed increase the economic output without jeopardizing natural resources. Evidence from works of literature is showing that natural resources are used to increase the income sustainably; as a remedy for the wrong traditional economic way (Allen, 2012; Harrison, 2015; Tara Rao, 2012). Lake zone of Tanzania being among the essential potential economic area has to reform the efforts and measures for the benefits of all. From the results, it is clear that some of the related sectors for the collection of the revenues are not well taken care of. There is a need also to strengthen the institutional quality, trade, and other sectors to attain better economic outputs.

Besides providing vital policy implications, this empirical study came across some limitations, as we could not explore the further informative determinants in-depth as other studies (Ascani et al., 2012; Manso et al., 2015) explained. The study has not explored the relationship between mentioned resources and the local community in terms of macroeconomic variables such as labor market, employment, exports and their impacts in the improvement of the local livelihood. This is because of unavailability of such data and unsystematic way of collecting them in the area, which makes it somehow biases. Despite these pitfalls, the results of this study give out a clear picture of the economic impact of two resources with extreme situations in the local areas. Government and other responsible authorities' cohorts should take actions accordingly, like putting efforts on the enforcement of available policies and regulations, provision of education and involvement of all important stakeholders in management and conservation activities. In addition to that, there should also be the formation and implementation of a crosscutting legal framework, which will sustainably increase economic outputs without jeopardizing natural resources and household livelihood.

\section{Conclusion}

This study uses cross-sectional data to determine the impact of fishery and forest resources on the local economic performance in one of the potential economic areas of Tanzania. The work used multiple linear regression analysis estimation on 30 councils in the lake zone of Tanzania and discussed some issues related to the appropriate local economy model estimation. The study found an insignificant economic impact of the abundant fishery resource on the local economic performance. Thus concludes that despite resource abundance being considered as an economic opportunity, results are indicating that responsible authorities in the local area still lack a good understanding of how fishery resources can be managed to generate economic prosperity and so influence the local councils' economy performance. While we find that, the presence of forest resources positively affects the local economy with a low economic impact. Again, the study also finds the presence of colleges and higher education institutions to have an insignificant impact; the number of medical doctors increases the council's economic performance, the number of hospitals and health centres to negative affect the councils economy. Thus, management and extractions of fishery and forest resources should also focus on sustainable income-generating activities, with the support of polices and other related elements. This new evidence provides some useful insight into the impact of natural resources in Tanzania and other developing counties, especially in the area with unique resources and economic features as the lake zone of Tanzania.

\section{References}

Abdipour, M., Younessi-Hmazekhanlu, M., \& Ramazani, S. H. R. (2019). Artificial neural networks and multiple linear regression as potential methods for modeling seed yield of safflower (Carthamus tinctorius L.). Industrial Crops and Products, 127, 185-194. https://doi.org/10.1016/j.indcrop.2018.10.050

Agrawal, A., Cashore, B., Hardin, R., Shepherd, G., Benson, C., \& Miller, D. (2013). Economic contributions of forests. Background Paper 1, United Nations Forum on Forerst Tenth Session 8-19 April 2013. Retrieved from https://pdfs.semanticscholar.org/64ec/13f6bf6671b10553caa43a1b864b3d99eaa6.pdf 
Albouy, D., \& Stuart, B. (2014). Urban population and amenities: The neoclassical model of location. NBER Working Papers 19919, National Bureau of Economic Research, Inc. https://doi.org/10.3386/w19919

Amin, S., \& Thirf, N. (1993). Globalization, Institutional Thickness and Local Prospects. Review of Regional and Urban Economics, 3, 405-427.

Aragón, F. M., Chuhan-Pole, P., \& Land, B. C. (2015). The local economic impacts of resource abundance: What have we learned? The World Bank. https://doi.org/10.1596/1813-9450-7263

Ascani, A., Crescenzi, R., \& Iammarino, S. (2012). Regional Economic Development. A Review. SEARCH WP01/03, 2-26. Retrieved from http://www.ub.edu/searchproject/wp-content/uploads/2012/02/WP-1.3.pdf

Batenburg, R., \& Rutten, R. (2003). Managing innovation in regional supply networks: A Dutch case of "knowledge industry clustering". Supply Chain Management: An International Journal, 8(3), 263-270. https://doi.org/10.1108/13598540310484654

Bloom, D. E., Canning, D., \& Sevilla, J. (2004). The effect of health on economic growth: A production function approach. World Development, 32(1), 1-13. https://doi.org/10.1016/j.worlddev.2003.07.002

Bronzini, R., \& Piselli, P. (2009). Determinants of long-run regional productivity with geographical spillovers: The role of R\&D, human capital and public infrastructure. Regional Science and Urban Economics, 39(2), 187-199. https://doi.org/10.1016/j.regsciurbeco.2008.07.002

Bucci, A., \& Segre, G. (2011). Culture and human capital in a two-sector endogenous growth model. Research in Economics, 65(4), 279-293. https://doi.org/10.1016/j.rie.2010.11.006

Cameron, A. S. C. (2012). A guidebook to the Green Economy Issue 1: Green Economy, Green Growth, and Low-Carbon Development - history, definitions and a guide to recent publications. Retrieved from https://sustainabledevelopment.un.org/content/documents/GE\%20Guidebook.pdf

Carlino, G. A., Chatterjee, S., \& Hunt, R. M. (2001). Knowledge spillovers and the new economy of cities. Economic Research Division, Federal Reserve Bank of Philadelphia. https://doi.org/10.21799/frbp.wp.2001.14

Cooke, P., Uranga, M. G., \& Etxebarria, G. (1998). Regional systems of innovation: An evolutionary perspective. Environment and Planning A, 30(9), 1563-1584. https://doi.org/10.1068/a301563

Courtney, P., \& Moseley, M. (2008). Determinants of local economic performance: Experience from rural England. Local Economy, 23(4), 305-318. https://doi.org/10.1080/02690940802408029

Crescenzi, R., \& Rodríguez-Pose, A. (2011). Reconciling top-down and bottom-up development policies. Environment and Planning A, 43(4), 773-780. https://doi.org/10.1068/a43492

Cuaresma, J. C., Danylo, O., Fritz, S., McCallum, I., Obersteiner, M., See, L., \& Walsh, B. (2017). Economic development and forest cover: evidence from satellite data. Scientific reports, 7, 40678. https://doi.org/10.1038/srep40678

Ewers, R. M. (2006). Interaction effects between economic development and forest cover determine deforestation rates. Global environmental change, 16(2), 161-169. https://doi.org10.1016/j.gloenvcha.2005.12.001

Gibbons, M., Limoges, C., Nowotny, H., Schwartzman, S., Scott, P., \& Trow, M. (1994). The new production of knowledge: The dynamics of science and research in contemporary societies. Sage Publications, Inc.

Glaeser, E. L. (2007). The economics approach to cities. NBER Working Papers 13696, National Bureau of Economic Research, Inc. Retrieved from https://www.nber.org/papers/w13696.pdf

Glaeser, E. L., \& Gyourko, J. (2006). Housing dynamics. NBER Working Paper 12787, National Bureau of Economic Research, Inc. https://doi.org/10.3386/w12787

Goletsis, Y., \& Chletsos, M. (2011). Measurement of development and regional disparities in Greek periphery: A multivariate approach. Socio-Economic Planning Sciences, 45(4), 174-183. https://doi.org/10.1016/j.seps.2011.06.002

Hsieh, C. T., \& Moretti, E. (2019). Housing constraints and spatial misallocation. American Economic Journal: Macroeconomics, 11(2), 1-39. https://doi.org/10.1257/mac.20170388

Iammarino, S. (2005). An evolutionary integrated view of regional systems of innovation: Concepts, measures and historical perspectives. European Planning Studies, 13(4), 497-519. https://doi.org/10.1080/09654310500107084 
Jackson, J., \& Murphy, P. (2006). Clusters in regional tourism An Australian case. Annals of Tourism Research, 33(4), 1018-1035. https://doi.org/10.1016/j.annals.2006.04.005

Jin, H., Qian, Y., \& Weingast, B. R. (2005). Regional decentralization and fiscal incentives: Federalism, Chinese style. Journal of Public Economics, 89(9-10), 1719-1742. https://doi.org/10.1016/j.jpubeco.2004.11.008

Kabubu, J. (2012). Tanzania embarks on road to green economy. Retrieved from https://wwf.panda.org/?205327/Tanzania-Embarks-on-Road-to-Green-Economy/

Kideghesho, J. R. (2015). Realities on deforestation in Tanzania-Trends, drivers, implications and the way forward. In Z. Miodrag (Ed.), Precious Forests-precious Earth (pp. 21-47). Intech Open Science/Open Minds, Rijeka. https://doi.org/10.5772/61002

Kmezić, S., \& Đulić, K. (2018). Serbia: Local Government Financing and Non-transparency of Fiscal Data. In W. Bartlett, S. Kmezić, \& K. Đulić (Eds.), Fiscal Decentralisation, Local Government and Policy Reversals in Southeastern Europe (pp. 83-121). Springer. https://doi.org/10.1007/978-3-319-96092-0_4

Kuznets, S., \& Murphy, J. T. (1966). Modern economic growth: Rate, structure, and spread (2nd ed.). New Haven: Yale University Press.

Lee, S. I., Lee, J., \& Hwang, B. (2019). Microstructure-based prediction of yield ratio and uniform elongation in high-strength bainitic steels using multiple linear regression analysis. Materials Science and Engineering A, 758, 56-59. https://doi.org/10.1016/j.msea.2019.04.113

Luomba, J. O., \& Onyango, P. O. (2012). Dagaa Fishery: The Unknown Wealth of Lake Victoria. International Institute of Fisheries Economics and Trade, Tanzania Proceeding. Retrieved from https://pdfs.semanticscholar.org/7807/2dc55177bb6c156a8a8cf7955379f535690a.pdf

Madrian, B. C. (2014). Applying insights from behavioral economics to policy design. Annu. Rev. Econ., 6(1), 663-688. https://doi.org/10.1146/annurev-economics-080213-041033

Mankiw, N. G. (2014). Principles of macroeconomics. Cengage Learning.

Manso, J. R. P., de Matos, A. J. F., \& Carvalho, C. C. (2015). Determinants of regional growth in Portugal: An empirical analysis. Economics \& Sociology, 8(4), 11. https://doi.org/10.14254/2071-789X.2015/8-4/1

Mgale, Y. J., \& Nikusekela, N. E. (2017). Decline in Fish Stock and Livelihood of Small-Scale Fisheries in Shores of Lake Victoria, Tanzania. International Journal of Applied Agricultural Sciences, 3(4), 87-91. https://doi.org/10.11648/j.ijaas.20170304.11

Mgaya, E. (2016). Forest and Forestry in Tanzania: Changes and Continuities in Policies and Practices from Colonial Times to the Present. Journal of the Geographical Association of Tanzania, 36(2), 45-58.

Milanovic, B. (2005). Half a world: regional inequality in five great federations. Research working paper; no. WPS 3699. Washington, DC, The World Bank. https://doi.org/10.1596/1813-9450-3699

NAFORMA. (2015). National Forest Resources Monitoring and Assessment of Tanzania Mainland: Main results 2009 to 2014.2 Retrieved from http://www.fao.org/forestry/43612-09cf2f02c20b55c1c00569e679197dcde.pdf

Nicholas, H. (2015). Benefits of a Green Economy Transformation in Sub-Saharan Africa, Federal Ministry for Economic Cooperation and Development. Retrieved from https://www.giz2015-0418en-benefits-green-economypdf/

Odongkara, K., Abila, R., \& Onyango, P. (2005). Distribution of economic benefits from the fisheries of Lake Victoria. Paper presented at the Proceedings of the Lake Victoria stakeholders conference: Meeting the challenges to sustainability of the fisheries resources. Retrieved from https://www.oceandocs.org/bitstream/handle/1834/2128/WLCK-87-92.pdf;jsessionid=15821E024627CDC1 4105B7432BB2D730? sequence $=1$

Peters, M., Simsek, A., \& Acemoglu, D. (2009). Solutions manual for introduction to modern economic growth. Princeton, NJ.: Princeton University Press.

Philippot, L.M. (2010). Natural resources and economic development in transition economies. Paper presented at the international conference Environment and Natural Resources Management in Developing and Transition Economies, Clermont-Ferrand. from http://citeseerx.ist.psu.edu/viewdoc/download?doi=10.1.1.193.6961\&rep=rep1\&type=pdf

Pike, A., Rodríguez-Pose, A., \& Tomaney, J. (2010). Handbook of local and regional development. Oxford: 
Routledge. https://doi.org/10.4324/9780203842393

Rodríguez-Pose, A., \& Crescenzi, R. (2008). Mountains in a flat world: Why proximity still matters for the location of economic activity. Cambridge Journal of Regions, Economy and Society, 1(3), 371-388. https://doi.org/10.1093/cjres/rsn011

Rutten, R., \& Boekema, F. (2007). Regional social capital: Embeddedness, innovation networks and regional economic development. Technological Forecasting and Social Change, 74(9), 1834-1846. https://doi.org/10.1016/j.techfore.2007.05.012

Scott, A., \& Storper, M. (2003). Regions, globalization, development. Regional Studies, 37(6-7), 579-593. https://doi.org/10.1080/0034340032000108697

Sharma, R. (2009). Sustainable development: The way for future, where are we? Indian Journal of Community Medicine: Official Publication of Indian Association of Preventive \& Social Medicine, 34(4), 276. https://doi.org/10.4103/0970-0218.58381

Sharma, R. (2018). Health and economic growth: Evidence from dynamic panel data of 143 years. PloS one, 13(10), e0204940. https://doi.org/10.1371/journal.pone.0204940

Solarin, S. A., Al-Mulali, U., Musah, I., \& Ozturk, I. (2017). Investigating the pollution haven hypothesis in Ghana: an empirical investigation. Energy, 124, 706-719. https://doi.org/10.1016/j.energy.2017.02.089

Soukiazis, E., \& Antunes, M. (2011). Is foreign trade important for regional growth? Empirical evidence from Portugal. Economic Modelling, 28(3), 1363-1373. https://doi.org/10.1016/j.econmod.2011.02.023

Tara Rao, T. R., Srinivas, K., George, J., Lo, S. P. (2012). Building an Equitable Green Economy. Retrieved from http://www.sagreenfund.org.za/wordpress/wp-content/uploads/2015/04/Building-an-Equitable-Green-Econo my.pdf

Terluin, I. J. (2003). Differences in economic development in rural regions of advanced countries: An overview and critical analysis of theories. Journal of Rural Studies, 19(3), 327-344. https://doi.org/10.1016/S0743-0167(02)00071-2

URT. (2012). National Report for the United Nations Conference on Sustainable Development, Rio+20. United Republic of Tanzania. Retrieved from https://sustainabledevelopment.un.org/content/documents/980tanzania.pdf

URT. (2018a). Minister speech on ministry's budget 2018-19, Dodoma- Ministry of fishery and livestock development. United Republic of Tanzania. Retrieved from https://www.mifugouvuvi.go.tz/publications/31

URT. (2018b). Sub-Divisional Population Projection for Year 2016 and 2017 Based on 2012 Population and Housing Census. . Retrieved from http://www.nbs.go.tz/nbs/takwimu/census2012/Tanzania_Total_Population_by_District-Regions-2016_201 7r.pdf

Van der Ploeg, F., \& Poelhekke, S. (2009). Volatility and the natural resource curse. Oxford Economic Papers, 61(4), 727-760. https://doi.org/10.1093/oep/gpp027

Wu, S., Li, L., \& Li, S. (2018). Natural resource abundance, natural resource-oriented industry dependence, and economic growth: Evidence from the provincial level in China. Resources, Conservation and Recycling, 139, 163-171. https://doi.org/10.1016/j.resconrec.2018.08.012

Zhang, X., \& Zhang, K. H. (2003). How does globalisation affect regional inequality within a developing country? Evidence from China. Journal of Development Studies, 39(4), 47-67. https://doi.org/10.1080/713869425

Zhihong, Z., Abdulrahman, A. S., \& Xiaoying, Z. (2014). Rural Governance Development in the Context of the New-Type Urbanization in Tanzania: A Comparison with China. Canadian Social Science, 10(4), 47. https://doi.org/10.3968/4669

\section{Copyrights}

Copyright for this article is retained by the author(s), with first publication rights granted to the journal.

This is an open-access article distributed under the terms and conditions of the Creative Commons Attribution license (http://creativecommons.org/licenses/by/4.0/). 